\title{
Extraction and Evaluation of Anti-Oxidants from Fruit Peels and Its Utilization in Paneer to Increase its Shelf-Life
}

\author{
Sanchita Choubey ${ }^{1}$, Gauri Katekar ${ }^{2}$, Pooja Pawar ${ }^{3}$ \\ and Suchitra Godbole ${ }^{4}$
}

\author{
1,2,3,4 Department of Microbiology/Dr. D. Y. Patil Arts, Commerce and Science College, \\ Sant Tukaram Nagar Pimpri, Pune, Maharashtra 411033, India
}

\begin{abstract}
Fruits are the potential source of natural antioxidants and produce antioxidative compounds in order to survive and counteract with reactive oxygen species. Synthetic antioxidants like BHT ((Butylated hydroxytoluene) and BHA (Butylated hydroxyanisole ) are generally used in food products which are toxic and may cause health hazards. Fruit peels like pomegranate, lemon and orange are normally wasted during fruit processing, thus a proper waste utilization of these peels should be done. The present study was undertaken to explore with the objective to extract antioxidants in the form of phenols and flavonoids from fruit peels like pomegranate, lemon and orange peels and to determine their antioxidant activity. Home-made paneer samples were prepared with addition of natural antioxidant extracts from these peels and were subjected to sensory studies and physical parameters were analysed for 5 days. This study supports the use of fruit peel extracts as antioxidants and antimicrobials, because active bimolecules in all the three extracts exhibit antimicrobial activity to a considerable extent and results in increasing the shelf life of home-made paneer up to 5 days of storage.
\end{abstract}

Key Words Antioxidant activity, Total phenolic content, Total flavonoid content, FRAP, Fruits peels

\section{Introduction}

Fruits are considered as an important part of a good diet. They are known to reduce risk of several chronic diseases. Fruits contain significant amounts of bioactive constituents. Fruits and vegetables wastes and their by-product are formed in great amounts during industrial processing and hence represent a serious problem, as they exert harmful impact on environment [1].

Fruits processing in India generate substantial quantities of waste. It had been previously reported that these wastes and by-products of fruits are an abundant source of antioxidant polyphenols [2].

Fruits peels are the major by-products obtained during the processing of various fruits and some studies show that these are good sources of polyphenols, carotenoids and other bioactive compounds which possess various beneficial effects on human health. Different components having activities like antimicrobial, antioxidant and anti-cancers [3, 4]. These peels and pomace are a source of sugars, minerals and organic acids, dietary fibers and phenolics which have a wide range of actions which includes antioxidants, antimutagenic, cardio preventive, antibacterial and antiviral activities [5]

Antioxidants are chemical substances that reduce or prevent oxidation and have the ability to counteract the damaging effects of free radicals in tissues, and thus are believed to protect against cancer, heart disease and several other diseases and also as a food additives like paneer,oil, breads, cookies etc. fruit peels consist of phenol contents which has a great role of an antioxidants [6]. These antioxidants are an especially important class of preservatives because like bacterial or fungal spoilage, oxidation reactions also occur relatively rapidly in frozen or refrigerated food causing their spoilage [7].

Tropical fruit is the fruit that grown in the tropical climates. Most of the biologically active substances, such as antioxidant are present in fruits [8]. The common type of antioxidants found in 
fruits are carotenoids, phenolic, vitamin A, B, C and $\mathrm{E}$. Fruit which is rich in natural antioxidants gained increasing interest among consumers and the scientific community, because it is vital in reducing the occurrence of degenerative diseases, like cardiovascular diseases, inflammation, ageing and cancer [9].

Fruit residues are by-product of many fruit processing industry, research has shift to focus on fruit residues as potential source of antioxidant. Despite stem bark, leaves, pulp and other part of the fruit, peels are preferable as it is the major byproduct that causing environmental problem. The discarded fruit peels are easily available and mostly contain potential antioxidants. The peels of orange, lemon and pomegranate are a source of sugars, minerals and organic acids, dietary fibers and phenolics which have a wide range of actions which includes antioxidants, antimutagenic, cardio preventive, antibacterial and antiviral activities [10].

Among various fruits are important as a naturally antioxidant source.

Lemon (Citrus limon Burm. cv. Eureka), a perennial tree in the family Rutaceae, is an important type of citrus tree in Taiwan due to its nutritionally rich juice and uniquely aromatic peels [11].

Pomegranate fruit products have been used for centuries since ancient civilizations for medicinal purposes. Stomachic, inflammation, fever, bronchitis, diarrhoea, dysentery, vaginitis, urinary tract infection, and, among others, malaria have been treated using various parts of pomegranate including fruit peels [12, 13, 14]. Moreover, increasing numbers of pomegranate supplements and products (functional foods, therapeutic formulae and cosmetics) are also available in markets $[15,16]$. The pomegranate tree is native to Asia and Middle East countries. Recently pomegranate fruit has drawn attention of many investigators because of its antioxidant compounds such as tannins and flavonoids. These phenolic compounds are responsible for its exceptional healing qualities [17].

Orange(Citrus sinensis) Citrus is genus of flowering plants in the family Rutaceae, native to tropical and subtropical areas in Southeast Asia. Citrus fruits have peculiar fragrance partly due to flavonoids and limonoids present in the peel and these fruits are good sources of vitamin $\mathrm{C}$ and flavonoids [18].
Use of waste fruit peels as a source of polyphenols and antioxidants may have considerable economic benefit to food processors. Therefore a cheap, efficient and environmentally sound utilization of these wastes is needed. Paneer is an important Indian traditional coagulated dairy product that provides sound nutrition, variety, safety, novelty of flavour, texture, portability and profitability to consumers. It is an acid coagulated dairy product, which is similar to western cottage cheese and Tofu (Soy paneer). In India, paneer production has been largely confined to small non-organized sectors. It is estimated that $1 \%$ of the country's total milk production is converted into paneer. Paneer represents one of the soft varieties of cheese family and is used in culinary dishes/snacks. About $5 \%$ of milk produced in India is converted into paneer of all the milk constituents [19].

Antioxidants are used as food additives to guard against food deterioration. These are added to food products like oil, bread, cookies, biscuits and dairy products like paneer to enhance their shelf life by preventing lipid peroxidation and protecting from oxidative damage [20].

Synthetic antioxidants generally used in food products like BHT and BHA are toxic and may cause health hazards. BHA (Butylated hydroxyanisole) has been added to edible fats and fat-containing foods for its antioxidant properties as it prevents rancidification of food which creates objectionable odors. Even though the National Toxicology Program classifies it as "reasonably anticipated to be a human carcinogen," the international cancer agency categorizes it as a possible human carcinogen, and it's listed as a known carcinogen under California's Proposition 65 While BHT (Butylated hydroxytoluene), is bad for the respiratory system. It can cause pulmonary ademonas and respiratory tract irritation. If consumed in large amount it can inhibit the humoral immune response in human. Though many synthetic antioxidants are available they possess some side effects and toxic property on human health [21].

Natural antioxidants peels pomegranate, lemon and orange were extracted and then utilized in paneer to increase their shelf life by preventing peroxide formation. Thus these natural antioxidants could be added to any food product containing fat and oil to increase their shelf life. 


\section{Material and Methods}

\subsection{Materials Required:}

Sample collection of different fruit peels from nearby fruit market- lemon, orange and pomegranate. Fresh milk (Buffalo milk) was collected for the preparation of paneer from local dairy at Chinchwad Pune.

\subsection{Extraction of antioxidants [22]}

The dried powders of peels of lemon, orange and pomegranate were extracted by Soxhlet extractor using ethanol as a solvent. $20 \mathrm{~g}$ of the dried powder was taken in $200 \mathrm{ml}$ of ethanol in conical flask. Extraction was carried out at $70^{\circ} \mathrm{C}$. After extraction the solvent is removed, typically by means of a rotary evaporator, yielding the extracted compound. The non-soluble portion of the extracted solid remains in the thimble, and is usually discarded. The extract was stored at $4^{\circ} \mathrm{C}$ in refrigerator.

2.3 Evaluation of anti-oxidants by Ferric reducing antioxidant power assay- (FRAP) [23, 24]

The total antioxidant activity can be measured by the ferric reducing antioxidant power assay (FRAP). The flavonoids and phenolic acids are present in the medicinal plant exhibit strong antioxidant activity which is depending on their potential to form the complex with metal atoms, particularly iron and copper. The antioxidant compound present in the samples forms a colored complex with potassium ferricyanide, trichloroacetic acid and ferric chloride, which is measured at $700 \mathrm{~nm}$ by UV Spectrophotometer

Ethanolic extract of lemon, orange and pomegranate $(30 \mu \mathrm{g} / \mathrm{mL})$ was added to $2.5 \mathrm{~mL}$ of $0.2 \mathrm{M}$ sodium phosphate buffer $(\mathrm{pH} 6.6)$ and 2.5 $\mathrm{mL}$ of $1 \%$ potassium ferricyanide $[\mathrm{K} 3 \mathrm{Fe}(\mathrm{CN}) 6]$ solution. The reaction mixture was vortexed well and then incubated at $50^{\circ} \mathrm{C}$ for $20 \mathrm{~min}$ using vortex mixer. At the end of the incubation, $2.5 \mathrm{~mL}$ of $10 \%$ trichloroacetic acid was added to the mixture and centrifuged at $3,000 \mathrm{rpm}$ for $10 \mathrm{~min}$. The supernatant $(2.5 \mathrm{~mL})$ was mixed with $2.5 \mathrm{~mL}$ of deionised water and $0.5 \mathrm{~mL}$ of $0.1 \%$ ferric chloride. The colored solution was read at $700 \mathrm{~nm}$ against the blank with reference to standard using UVSpectrophotometer. Here, ascorbic acid was used as a reference standard, the reducing power of the samples were comparable with the reference standard.

\subsection{Determination total phenolic contents by Ferric chloride test [25]}

The total phenolic concentration could be used as a basis for rapid screening of antioxidant activity. The $10 \mathrm{ml}$ extract was treated with 2-3 drops of ferric chloride solution. Formation of bluish color indicates the presence of phenols.

\subsection{Determination of total flavonoid contents by Shinoda test [25]}

Four pieces of magnesium filings are added to the ethanolic extract followed by few drops of concentrated hydrochloric acid. A pink or red colour indicates the presence of flavonoid. Colours varying from orange to red indicated flavones, red to crimson.

\subsection{Preparation of Paneer with fruit peel extracts}

1 Liter of whole cow milk was taken. 1-2 table spoon of lemon juice was used to split the milk for paneer to be formed. The milk was brought to a temperature just below boiling and lemon juice was added to boiling milk. It was allowed to curdle and cool. After cooling whey was separated by filtering through cotton/muslin cloth. Whey was drained from the paneer and paneer was cut it into rectangular block. It was kept at cold temperature to form soft and firmer texture. Paneer was prepared with different concentrations $1 \%, 2 \% \&$ $3 \%$ extracts of lemon, orange and pomegranate and paneer without the addition of fruit peel extract was kept as control.

\subsection{Sensory analysis [26]}

The Sensory evaluation of paneer was carried out by a 10 member panel comprised of students and academic staff members. The panel members were requested in measuring the terms identifying sensory characteristics and in use of the score. Judgments were made through rating products on a 9 point hedonic scale with corresponding descriptive terms ranging from 9 'like extremely' to 1 'dislike extremely'.

\subsection{Isolation \&Identification of microbial isolates from paneer samples}

Effect of antioxidants on paneer sample was determined over 5 days of storage and microbial count was taken on $1^{\text {st }}$ day, $3^{\text {rd }}$ and $5^{\text {th }}$ day of storage of paneer at $4^{\circ} \mathrm{C}$. $10 \mathrm{gm}$ samples were aseptically suspended in $100 \mathrm{ml}$ of nutrient broth medium and shaken for 10 minutes at room temperature, and samples were serially diluted up 
to $10^{-3}$. Dilutions were spread on sterile Nutrient agar (NA) plates. The plates were incubated at $37^{\circ} \mathrm{C}$ for $24-48 \mathrm{~h}$. After incubation the isolated colonies were obtained in pure culture and identified up to genus level. All bacterial isolates were identified based on their colony characteristics, morphological characteristics and biochemical reactions.

\subsection{Determination of antimicrobial activity of lemon, orange and pomegranate against identified strains [27]}

Antimicrobial effect was determined on sterile MH- agar (Muller-Hilton agar) plates by the disk diffusion method of Kirby and Bauer. Plates were have gained considerable interest in recent years for their role in preventing the auto oxidation of fats, oils and fat containing food products. Different studies conducted on peels revealed the presence of important constituents, which can be used for pharmacological or pharmaceutical purpose. Citrus fruits such as lemon and orange are one of the world's most important fruit crops, and are known for their nutritive values and special aroma. Citrus is mainly consumed as fresh fruit or juice. Many in-vivo and in-vitro studies have reported citrus fruit to be effective against many chronic diseases, such as cancers and vascular diseases antimicrobial, anti-inflammatory and proliferative etc. have been isolated from different peels [28].

Pomegranate fruit products have been used for centuries since ancient civilizations for medicinal purposes. Stomach inflammation, fever, bronchitis, diarrhea, dysentery, urinary tract infection and among others malaria have been treated using seeded with different microbial cultures. When a 6$\mathrm{mm}$ filter paper disk impregnated with a known concentration of an antimicrobial compound is placed on a Mueller-Hinton ( $\mathrm{MH})$ agar plate, immediately water is absorbed into the disk from the agar. The antimicrobial begins to diffuse into the surrounding agar. The plates were incubated overnight at $37^{\circ} \mathrm{C}$. After incubation the zones of inhibition were measured and recorded.

\section{Results and Discussion}

Natural antioxidants could be added to any food product containing fat and oil to increase their shelf life by preventing rancidity. Natural antioxidants

various parts of pomegranate including fruit peels. Moreover, increasing numbers of pomegranate supplements and products (functional foods, therapeutic formulae and cosmetics) are also available in markets [29].

The microbiological quality of paneer depends on the microbiological quality of milk, and the hygiene exercised during manufacture of paneer The aim of this study was to extend the shelf life of fresh home-made paneer. The shelf life of paneer is only 1 day at room temperature and 6 days at $4^{\circ} \mathrm{C}$.

Identification of isolates obtained from samples were done by morphological characterization, microscopically by Gram staining, and various biochemical tests recommended in the Bergey's Manual of Determinative Bacteriology (Table 2) [30]. According to the tests, five organisms in Isolated may be Escherichia coli, Klebsiella spp., Staphylococcus spp., Pseudomonas spp, and Salmonella spp. (Table 2b).

Table 1: Enumeration of bacteria from paneer.

\begin{tabular}{|c|c|c|c|c|}
\hline$\underline{\text { Extracts }}$ & $\frac{\text { Concentration }}{(\%)}$ & $\frac{\text { CFU / 10g of paneer }}{\text { on 1st day }}$ & $\frac{\text { CFU / 10g of paneer }}{{\text { on } 3^{\text {rd }} \text { day }}^{\text {nat }}}$ & $\frac{\text { CFU / 10g of paneer }}{\text { on } 5^{\text {th }} \text { day }}$ \\
\hline \multirow[t]{3}{*}{ lemon } & 1 & $26 \times 10^{3}$ & $63 \times 10^{3}$ & TNTC \\
\hline & 2 & $9 \times 10^{3}$ & $75 \times 10^{3}$ & TNTC \\
\hline & 3 & $5 \times 10^{3}$ & $39 \times 10^{3}$ & $70 \times 10^{3}$ \\
\hline \multirow[t]{3}{*}{ Orange } & 1 & $17 \times 10^{3}$ & $49 \times 10^{3}$ & TNTC \\
\hline & 2 & $10 \times 10^{3}$ & $35 \times 10^{3}$ & TNTC \\
\hline & 3 & $6 \times 10^{3}$ & $28 \times 10^{3}$ & TNTC \\
\hline \multirow[t]{3}{*}{ pomegranate } & 1 & $14 \times 10^{3}$ & $58 \times 10^{3}$ & TNTC \\
\hline & 2 & $8 \times 10^{3}$ & $45 \times 10^{3}$ & TNTC \\
\hline & 3 & $4 \times 10^{3}$ & $21 \times 10^{3}$ & $40 \times 10^{3}$ \\
\hline Control & - & $41 \times 10^{3}$ & TNTC & TNTC \\
\hline
\end{tabular}

TNTC- Too numerous to count 
Table 2: Morphological, Biochemical and Physiological Characterization of the Microorganism

2 (a) Colony \& Morphological characteristics

\begin{tabular}{|l|c|c|c|c|c|}
\hline $\begin{array}{l}\text { Colony } \\
\text { characteristics }\end{array}$ & I & II & III & IV & V \\
\hline Size (mm) & 1 & 1 & 1 & 1 & 2 \\
\hline Shape & Circular & Circular & Circular & Irregular & Circular \\
\hline Color & Pink & Yellowish & Yellow & Greenish yellow & Dark pink \\
\hline Margin & Entire & Entire & Entire & Irregular & Entire \\
\hline Opacity & Opaque & Opaque & Opaque & Opaque & Opaque \\
\hline Elevation & Convex & Concave & Convex & flat & Concave \\
\hline Motility & Motile & Non motile & Non motile & Motile & Motile \\
\hline $\begin{array}{l}\text { Gram } \\
\text { character }\end{array}$ & $\begin{array}{c}\text { Gram negative } \\
\text { Short rods }\end{array}$ & $\begin{array}{c}\text { Gram negative } \\
\text { rods }\end{array}$ & Gram positive cocci & $\begin{array}{c}\text { Gram negative } \\
\text { rods }\end{array}$ & $\begin{array}{c}\text { Gram negative } \\
\text { rods }\end{array}$ \\
\hline
\end{tabular}

2 (b) Biochemical tests for the isolates

\begin{tabular}{|c|c|c|c|c|c|}
\hline Biochemiacal test & I & $\mathbf{I I}$ & III & IV & $\mathbf{V}$ \\
\hline $\begin{array}{c}\text { Sugar fermentation } \\
\text { Glucose } \\
\text { Fructose } \\
\text { Mannitol } \\
\text { Maltose } \\
\text { Lactose } \\
\text { Sucrose } \\
\text { Arabinose } \\
\text { Galactose }\end{array}$ & $\begin{array}{l}\text { +ve(AG) } \\
\text { +ve }(\mathrm{A}) \\
\text { +ve }(\mathrm{A}) \\
\text { +ve }(\mathrm{A}) \\
\text { +ve }(\mathrm{A}) \\
\text { +ve }(\mathrm{A}) \\
\text { +ve }(\mathrm{A}) \\
\text { +ve }(\mathrm{A})\end{array}$ & $\begin{array}{l}\text { +ve(AG) } \\
\text { +ve }(\mathrm{A}) \\
\text { +ve }(\mathrm{A}) \\
\text { +ve }(\mathrm{A}) \\
\text { +ve }(\mathrm{A}) \\
\text { +ve }(\mathrm{A}) \\
\text { +ve }(\mathrm{A}) \\
\text { +ve }(\mathrm{A})\end{array}$ & $\begin{array}{l}\text { +ve(AG) } \\
\text { +ve }(\mathrm{A}) \\
\text { +ve }(\mathrm{A}) \\
\text { +ve }(\mathrm{A}) \\
\text { +ve }(\mathrm{A}) \\
\text { + ve }(\mathrm{A}) \\
\text {-ve } \\
\text { +ve }(\mathrm{A})\end{array}$ & $\begin{array}{l}\text { +ve (AG) } \\
\text { +ve (A) } \\
\text { +ve (A) } \\
\text {-ve } \\
\text { +ve (A) } \\
\text { +ve (A) } \\
\text { +ve (A) } \\
\text { +ve (A) }\end{array}$ & $\begin{array}{l}\text { +ve(AG) } \\
\text { +ve }(A) \\
\text { +ve }(A) \\
\text { +ve }(A) \\
\text {-ve } \\
\text {-ve } \\
\text { +ve (A) } \\
\text { +ve (A) }\end{array}$ \\
\hline $\begin{array}{c}\text { IMVIC test } \\
\text { Indole test } \\
\text { Methyl Red } \\
\text { Voges Proskauer } \\
\text { Citrate utilization }\end{array}$ & $\begin{array}{l}\text { +ve } \\
\text { +ve } \\
\text {-ve } \\
\text { +ve }\end{array}$ & $\begin{array}{l}\text {-ve } \\
\text {-ve } \\
\text {-ve } \\
+ \text { ve }\end{array}$ & $\begin{array}{l}- \\
- \\
- \\
-\end{array}$ & $\begin{array}{l}- \\
- \\
- \\
-\end{array}$ & $\begin{array}{l}\text {-ve } \\
\text { +ve } \\
\text {-ve } \\
\text { +ve }\end{array}$ \\
\hline Gelatinase & -ve & -ve & - & +ve & -ve \\
\hline Nitrate reduction & +ve & +ve & +ve & +ve & +ve \\
\hline Oxidase test & - ve & - ve & - & +ve & - ve \\
\hline Catalase test & +ve & + ve & - & - & +ve \\
\hline -ve $=$ Negative,$+\mathrm{ve}=$ Positive & AG- Prodı & ion of acid and $g$ & $\mathrm{~A}-\mathrm{on}$ & $y$ acid productio & \\
\hline $\begin{array}{l}\text { Probable Genus level } \\
\text { Identification }\end{array}$ & $\begin{array}{c}\text { Escherichia } \\
\text { coli }\end{array}$ & Klebsiella spp. & $\begin{array}{l}\text { Staphylococcus } \\
\text { spp. }\end{array}$ & $\begin{array}{l}\text { Pseudomonas } \\
\text { spp. }\end{array}$ & $\begin{array}{l}\text { Salmonella } \\
\text { spp. }\end{array}$ \\
\hline
\end{tabular}

Table 2: Morphological, Biochemical and Physiological Characterization of the Microorganism (2 (a) Colony \& Morphological characteristics and 2 (b) Biochemical tests for the isolates)

Paneer was subjected to sensory acceptability. Table 3 shows the data of mean score of sensory acceptability of pomegranate, lemon and orange extract paneer samples. In the present study the antioxidants were in solution form and they were added in small amount $(1-3 \%)$ to the paneer sample. Data indicated that maximum score for overall acceptability of pomegranate, orange and 
lemon peels were at the level of 1- $2 \%$ of antioxidant extract. At the level of $3 \%$ it was not very acceptable because of the difference in the colour and appearance however there was no change in the taste, texture and flavour in the sample.

Table 3: Mean score of acceptability of paneer samples with extract of Pomegranate, Lemon \& Orange

\begin{tabular}{|c|c|c|c|c|c|c|}
\hline Sample & Color & Taste & Texture & Flavour & Appearance & $\begin{array}{c}\text { Overall } \\
\text { acceptability }\end{array}$ \\
\hline Control & 8.32 & 8.43 & 8.50 & 8.52 & 8.58 & 8.56 \\
\hline \multicolumn{7}{|l|}{ Pomegranate } \\
\hline $1 \%$ & 8.39 & 8.42 & 8.34 & 8.42 & 8.47 & 8.44 \\
\hline $2 \%$ & 8.25 & 8.32 & 8.32 & 8.31 & 8.23 & 8.43 \\
\hline $3 \%$ & 7.94 & 8.01 & 8.31 & 8.22 & 7.0 & 7.50 \\
\hline \multicolumn{7}{|l|}{ Lemon } \\
\hline $1 \%$ & 8.38 & 8.41 & 8.22 & 8.48 & 8.30 & 8.0 \\
\hline $2 \%$ & 8.27 & 8.35 & 8.24 & 8.40 & 8.26 & 8.19 \\
\hline $3 \%$ & 7.84 & 7.66 & 8.22 & 8.32 & 7.21 & 7.60 \\
\hline \multicolumn{7}{|l|}{ Orange } \\
\hline $1 \%$ & 8.36 & 8.40 & 8.20 & 8.47 & 8.29 & 7.98 \\
\hline $2 \%$ & 8.24 & 8.34 & 8.22 & 8.38 & 8.25 & 8.0 \\
\hline $3 \%$ & 7.80 & 7.63 & 8.19 & 8.30 & 7.20 & 7.40 \\
\hline
\end{tabular}

Data indicated that maximum score for overall acceptability of pomegranate, orange and lemon peels were at the level of $1-2 \%$ of antioxidant extract. At the level of $3 \%$ it was not very acceptable because of the difference in the color and appearance however there was no change in the taste, texture and flavour in the sample.

\section{Antioxidant activity}

Total antioxidant was determined by using FRAP assay (ferric reducing antioxidant power assay) along with phytochemical analysis. Ferric reducing antioxidant assay determination of total phenols, determination of total flavonoids was evaluated. The Absorbance was measured at $700 \mathrm{~nm}$ used UV-VIS Spectrometer. The optical density at 700 $\mathrm{nm}$ for orange extract was 0.059 , for lemon 0.081 \& pomegranate extract it was 0.112 which was closer to Ascorbic acid Standard (0.203). All three extracts showed bluish colour indicating the presence of phenols and pink or red colour indicating the presence of flavonoid.

\section{Antimicrobial activity}

The present study reveals that the highest antimicrobial activity was shown by pomegranate and lemon extract against all the isolated microorganisms (Fig: 1).

The zone of inhibition of fruit peel extrcts against isolated strains from paneer was measured to evaluate antimicrobial activity. Pomegranate has shown the antimicrobial activity with maximum zone of inhibition $33 \mathrm{~mm}$ against Klebsiella spp (Table 4). Lemon has shown the antimicrobial activity against all isolated strain and with maximum zone of inhibition $35 \mathrm{~mm}$ against Salmonella spp. Orange has shown the antimicrobial activity against E.coli and Pseudomonas spp. The results obtained with the fruit peel extracts against isolated organisms suggest that further studies of combination of all three extracts might provide encouraging results which might be exploited 
Fig: 1 (a-e) -Antimicrobial Activity of three extracts (lemon, orange and pomegranate) against isolated strains from paneer.

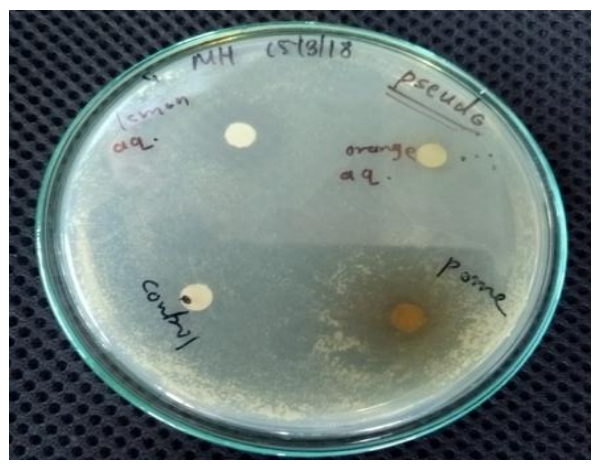

Fig 1 a- Antimicrobial activity of pomegranate, lemon \& orange extracts against Psuedomanas spp

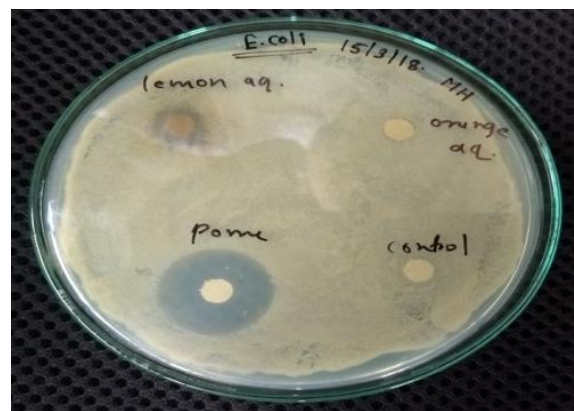

Fig 1 b- Antimicrobial activity of pomegranate, lemon \& orange extracts against $E$. coli spp

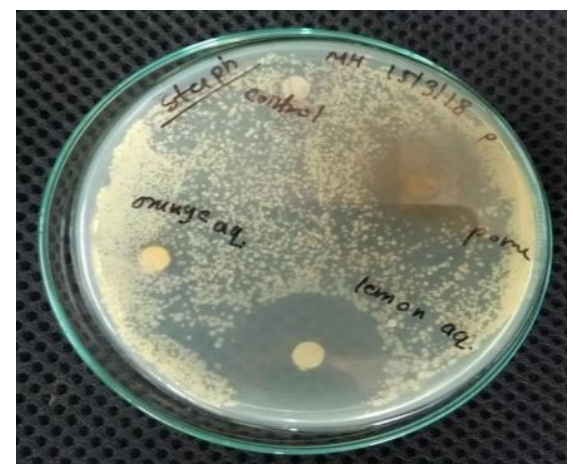

Fig $1 d$ - Antimicrobial activity of pomegranate, lemon \& orange extracts against Staphylococcus spp

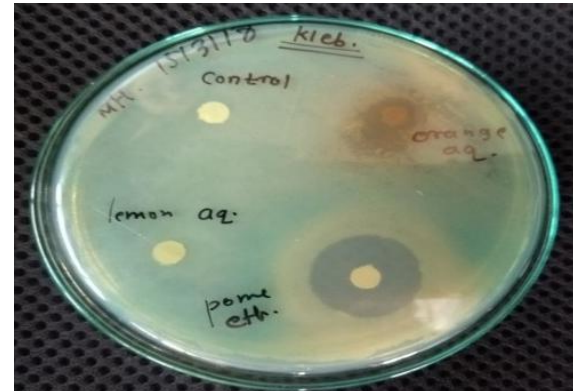

Fig 1 c- Antimicrobial activity of pomegranate, lemon \& orange extracts against Klebsiella spp

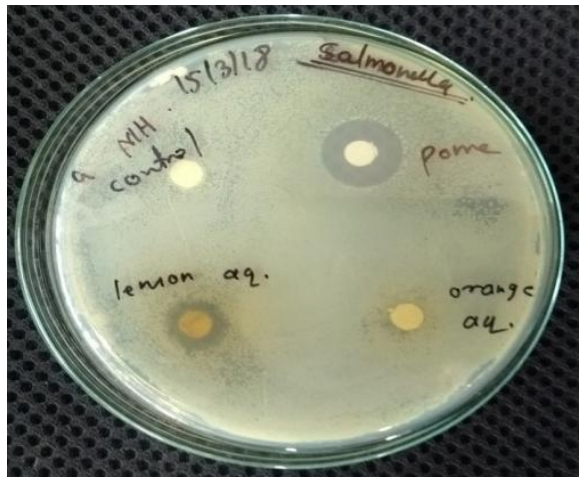

Fig $1 e$ - Antimicrobial activity of pomegranate, lemon \& orange extracts against Salmonella spp 
Table 4: Zone of inhibition against the isolated strains

\begin{tabular}{|l|c|c|c|c|c|}
\hline Extract & E.coli $\boldsymbol{s p p}$ & Klebsiella spp & Staphylococcus spp & Pseudomonas spp & Salmonella spp \\
\hline Lemon & $16 \mathrm{~mm}(\mathrm{~A})$ & $21 \mathrm{~mm}(\mathrm{E})$ & $23 \mathrm{~mm}(\mathrm{E})$ & $15 \mathrm{~mm}(\mathrm{~A})$ & $35 \mathrm{~mm}(\mathrm{~A})$ \\
& $14 \mathrm{~mm}(\mathrm{E})$ & $13 \mathrm{~mm}(\mathrm{~A})$ & $20 \mathrm{~mm}(\mathrm{~A})$ & & $13 \mathrm{~mm}(\mathrm{~A})$ \\
\hline Orange & $16 \mathrm{~mm}(\mathrm{~A})$ & - & - & $11 \mathrm{~mm}(\mathrm{~A})$ & - \\
\hline Pomegranate & $19 \mathrm{~mm}(\mathrm{E})$ & $33 \mathrm{~mm}(\mathrm{E})$ & - & $23 \mathrm{~mm}(\mathrm{E})$ & $18 \mathrm{~mm}(\mathrm{E})$ \\
\hline
\end{tabular}

E- Ethanol extract A-Aqueous extract.

\section{Conclusion}

The present work shows the phytochemical analysis and antimicrobial activity of the ethanolic extract of the fruits peels orange pomegranate and lemon. Various phytochemical analyses revealed the presence of flavonoids, polyphenols and citric acid. The total counts were increased during storage of paneer up to 5 days at $4^{\circ} \mathrm{C}$. The initial total plate count of control fresh paneer was comparatively high than that of with added extracts. The antimicrobial activity of the ethanolic extract of the plant showed significant result against all the isolated organisms from paneer. The antimicrobial activity of the fruit extract was examined against the characterized bacterial strains they were Staphylococcus spp, Escherichia coli, Klebsiella spp, Pseudomonas spp and Salmonella spp. However this study strongly supports the use of lemon, orange and pomegranate fruit peels as natural preservatives. It can be concluded that Maximum antioxidant activity was found in

\section{References}

[1] Dewick PM , Medicinal Natural Products. Wiley, Chichester : 121, (2002).

[2] Balasundram N, Sundaram K, Samman S., Phenolic compounds in plants Andagri-industrial [3] Sharma SK, Maguer M Le, Lycopene in tomatoes and tomato pulp fractions, Italian Journal of Food Science, 2:107-113, (1996).

[4] Lario Y, Sendra E, Garcia-Perez J, Fuentes C, Sayas-Barbera E, Fernandez-Lopez J, Preparation of high dietary fiber powder from lemon juice byproduct, Innovative Food Science and Emerging Technologies, 5: 113-117, (2004).

[5] Adams LS, Seeram NP, Agarwal BB, Takada Y, Sand D, et al., Pomegranate juice, total pomegranate ellagitannins, and punicalagin suppress inflammatory cell signaling in colon cancer cells, J Agric Food Chem , 54: 980-985, (2006) . pomegranate followed by lemon and minimum in orange peel. Pomegranate peels due to its high antioxidant activity, phenolic content and antimicrobial activity may prove to be a better substitute in place of synthetic antioxidants in extending the shelf life of food product by preventing the peroxide formation in the product containing fat and oil such as paneer. In addition natural antioxidants are safe and impart health benefit to the consumer. The results of sensory analyses of the paneer samples were also encouraging as it showed good score of acceptability with added natural peel extracts.

\section{Acknowledgements}

We wish to express our sincere thanks and gratitude to Principle \& Head of the department of Microbiology Dr. Snehal Agnihotri, Dr. D. Y.

Patil ACS College, Pimpri, Pune, for providing the necessary facilities to carry out this research

by-products: Antioxidant activity, occurrence, and potential uses, Food Chemistry, 99:191-203, (2006).

[6] Singh RP, Murthy KNC, Jayaprakasha GK, Studies on the antioxidant activity of pomegranate (Punicagranatum) peel and seed extracts using in vitro models, J Agric Food Chem, 50: 81-86, (2002).

[7] Singh $S$ and Immanuel $G$, Extraction of Antioxidants from Fruit Peels and its Utilization in Paneer, Journal of Food Processing \& Technology, 5(7):1-5, (2014) .

[8] Alothman M, Bhat $\mathrm{R}$ and Karim A, Antioxidant capacity and phenolic content of selected tropical fruits from Malaysia, extracted with different solvents, Food Chemistry, 115(3): 785-788, (2009) . 
[9] Thaipong K., Boonprakob U, Crosby K., Cisneros Zevallos L and Hawkins BD, Comparison of ABTS, DPPH, FRAP, and ORAC assays for estimating antioxidant activity from guava fruit extracts, Journal of Food Composition and Analysis, 19(6-7):669-675, (2006) .

[10] Helkar PB, Sahoo AK and Patil NJ, Review: Food Industry By-Products used as a Functional Food, International journal of waste resources, 6(3):1-6, (2016).

[11] Dhanavade MJ, Jalkute CB, Ghosh JS, Sonawane KD, Study Antimicrobial Activity of Lemon (Citrus lemon L.) Peel Extract, British Journal of Pharmacology and Toxicology, 2(3):119-122, (2011).

[12] Li Y, Guo C, Yang J, Wei J, Xu J and Cheng $\mathrm{S}$, Evaluation of Antioxidant Properties of Pomegranate Peel Extract in Comparison with Pomegranate Pulp Extract, Food Chemistry 96(2): 254-260, (2006).

[13] Reddy M, Gupta S, Jacob M, Khan S and Ferreira D, Antioxidant, Antimalarial and Antimicrobial Activities of Tannin-Rich Fractions, Ellagitannins and Phenolic Acids from Punica granatum L., Planta Medica 73(5):461-467, (2007).

[14] Iqbal S, Haleem S, Akhtar M, Zia-ul-Haq M and Akbar $\mathbf{J}$ Efficiency of Pomegranate Peel Extracts in Sta- bilization of Sunflower Oil under Accelerated Condi- tions, Food Research International, 41(2):194-200, (2008) .

[15] Negi P and Jayaprakasha J Antioxidant and Antibacte- rial Activities of Punica granatum Peel Extracts., Jour- nal of Food Science, 68(4):14731477, (2003).

[16] Madrigal-Carballo S, Rodriguez G, Krueger C, Dre- her $\mathbf{M}$ and Reed $\mathrm{J}$ Pomegranate (Punica granatum) Suppliment: authencity, Antioxidant and polyphenols composition, Journal of Functional Foods, 1(3):324-329, (2009).

[17] Adhami VM, Khan N, Mukhtar H., Cancer Chemoprevention by Pomegranate: Laboratory and Clinical Evidence, Nutrition Cancer , 61(6):811$815,(2009)$.

[18] Sawalha SMS, Arráez-Román D, SeguraCarretero A, Fernández-Gutiérrez A, Quantification of main phenolic compounds in sweet and bitter orange peel using CE- MS/M. Food Chemistry ,116:567-574, (2009) .
[19] Chandan RC, Gupta S (2007) Manufacturing of paneer. In Dairy India. Dairy India Yearbook: 411.

[20] Indrajit D. Thorata, Dipali D. Jagtapb, Debabandya Mohapatrac, D.C. Joshib, R.F. Sutarb, and S.S. Kapdib (2013) Antioxidants, their properties uses in food products and their legal implications. International Journal of Food Studies 2:81-104.

\section{[21] NTP 2011, IARC 1986, OEHHA 2014.}

[22] Preethi S and Mary Saral A, Optimization of Green Methods for Extraction of Polysaccharides from Fruits of Pithecellobium dulce, Asian Journal of Chemistry, 30 (2):246-248, (2018).

[23] Maruthamuthu Vijayalakshmi and Kandasamy Ruckmani , Ferric reducing anti-oxidant power assay in plant extract, India, Bangladesh . J Pharma col, 11: 570-5 72, (2016).

[24] Oyaizu M., Studies on product of browning reaction prepared from glucose amine, Jpn J Nutr, 44: 307-15, (1986).

[25] Sumalatha BV, Devprakash1, Senthil Kumar GP, Mani T, Isolation of Flavonol of Tephrosia purpurea, Research Journal of Pharmaceutical, Biological and Chemical , 3(3):105-110, (2012) .

[26] D.R. and Pilgrim, F.J., Hedonic scale method of measuring food preferences, Food Technology 9-14, (1957).

[27] Hudzicki J, Kirby-Bauer Disk Diffusion Susceptibility Test Protocol. American Society for Microbiolog (2009).

[28] Shie PH and Lay HL, Component analysis and antioxidant activity of Citrus limon, Academia Journal of Medicinal Plants, 1(3):049-058, (2013).

[29] Bhowmik D, Gopinath H, Kumar BP, Duraivel S, Aravind G, Sampath Kumar KP, Medicinal Uses of Punica granatum and Its Health Benefit, Journal of Pharmacognosy and phytochemistry 1(5):28-35, (2013).

[30] Holt JG, Krieg NR, Sneath HA, Staley JT, Williams ST, Bergey's Manual of Determinative bacteriology, Williams and Wilkins U.S.A 9, (1994) . 